\title{
Nocardioides fonticola sp. nov., a novel actinomycete isolated from spring water
}

Correspondence
Wen-Ming Chen
p62365@ms28.hinet.net

\author{
Jui-Hsing Chou, ${ }^{1}$ Nian-Tsz Cho, ${ }^{2}$ A. B. Arun, ${ }^{1}$ Chiu-Chung Young ${ }^{1}$ \\ and Wen-Ming Chen ${ }^{2}$
${ }^{1}$ Department of Soil Environmental Science, College of Agriculture and Natural Resources, National Chung Hsing University, Taichung, Taiwan, ROC University, 142 Hai-Chuan Road, Nan-Tzu, Kaohsiung City 811, Taiwan, ROC \\ ${ }^{2}$ Laboratory of Microbiology, Department of Seafood Science, National Kaohsiung Marine
}

The genus Nocardioides (Prauser, 1976, 1989) belongs to the family Nocardioidaceae, a member of the suborder Propionibacterineae proposed by Stackebrandt et al. (1997). At the time of writing, this genus encompassed 23 species with validly published names (http://www.bacterio.cict.fr/ n/nocardioides.html). Nocardioides species are widely distributed in soil and aquatic habitats, including marine sediments. All of these taxa have been isolated from natural and man-made habitats including soil, herbage, groundwater, river water, industrial wastewater, an oil-shale column, black sand, crude oil, a saline lake and a tidal flat (Yoon et al., 1997, 2004, 2007a, b; Lee, 2007; Choi et al., 2007).

The aim of the present study was to determine the taxonomic position of an actinomycete, strain $\mathrm{NAA}-13^{\mathrm{T}}$, that formed a pale yellow colony on an R2A agar (Difco) plate that had been incubated at $25{ }^{\circ} \mathrm{C}$ for 3 days following inoculation with a water sample collected from a

Abbreviation: DAP, diaminopimelic acid.

The GenBank/EMBL/DDBJ accession number for the 16S rRNA gene sequence of strain NAA-13 ${ }^{\top}$ is EF626689.

A table showing the cellular fatty acid composition of strain NAA-13 ${ }^{\top}$ grown on R2A agar is available with the online version of this paper. freshwater spring, Kaoshiung County, Taiwan. The organism was the subject of a polyphasic taxonomic study.

Subcultivation of this strain was performed on R2A agar at $25{ }^{\circ} \mathrm{C}$ for between 48 and $72 \mathrm{~h}$. The strain was preserved by lyophilization with $20 \%(\mathrm{w} / \mathrm{v})$ skimmed milk. Bacterial cells were observed by light and phase-contrast microscopy (DM2000; Leica) in the lag, exponential and stationary phases of growth to ascertain their morphology. Cell dimensions were measured with ocular $(\times 10)$ and objective $(\times 100 / 1.25$ numerical aperture $)$ lenses. Motility of cells was tested by using the hanging-drop method. The Spot Test flagella stain (BD Difco) was used to stain any flagella that might be present. A Gram stain set (BD Difco) and the Ryu non-staining $\mathrm{KOH}$ method (Powers, 1995) were used to ascertain the Gram reaction of strain NAA$13^{\mathrm{T}}$. Acid-fastness was determined by Ziehl-Neelsen staining (Hendrickson \& Krenz, 1991). Poly- $\beta$-hydroxybutyrate granule accumulation was observed under light microscopy after staining cells with Sudan black (Smibert \& Krieg, 1994). Colony morphology was examined using a stereoscopic microscope (SMZ800; Nikon). The pH range for growth was examined in nutrient broth (BD Difco) with the appropriate biological buffers ( $\mathrm{pH} 4-10$, at increments of $0.5 \mathrm{pH}$ units) (Chung et al., 1995). Tolerance to various $\mathrm{NaCl}$ concentrations was tested in 
nutrient broth prepared according to the formula of the Difco medium, except that the $\mathrm{NaCl}$ concentration was altered as required $(0,0.5$ and $1.0-10 \%, \mathrm{w} / \mathrm{v}$, at increments of $1.0 \%)$. Growth at various temperatures $\left(4-45^{\circ} \mathrm{C}\right)$ was measured in nutrient broth. Cellular growth was determined by measuring the turbidity $\left(\mathrm{OD}_{600}\right)$ of cultures grown at various $\mathrm{pH}$ values, $\mathrm{NaCl}$ concentrations and temperatures. Anaerobic cultivation was performed on nutrient or R2A agar using the Oxoid AnaeroGen system.

Extraction of genomic DNA, PCR amplification and sequencing of the $16 \mathrm{~S}$ rRNA gene were carried out as described previously (Chen et al., 2001). Sequence analysis was achieved using a DNA sequencer (ABI Prism 310; Applied Biosystems) and sequences were assembled by using the Fragment Assembly System program from the Wisconsin package version 9.1 (GCG, 1995). An almostcomplete 16S rRNA gene sequence (1403 nt) of strain NAA $-13^{\mathrm{T}}$ was compared against $16 \mathrm{~S}$ rRNA gene sequences available from the Ribosomal Database Project and GenBank. Multiple sequence alignment including strain NAA- $13^{\mathrm{T}}$ and its closest relatives was performed using BioEdit software (Hall, 1999) and MEGA version 3.1 (Kumar et al., 2004). Phylogenetic trees were inferred by using the maximum-likelihood (Felsenstein, 1981), maximum-parsimony (Kluge \& Farris, 1969) and neighbour-joining (Saitou \& Nei, 1987) algorithms. An evolutionary distance matrix was generated for the neighbour-joining algorithm by using the Jukes \& Cantor (1969) distance model; bootstrap analysis for the neighbour-joining tree was performed on the basis of 1000 resamplings. A comparison of the $16 \mathrm{~S}$ rRNA gene sequence of strain NAA- $13^{\mathrm{T}}$ with those of members of genera listed under the family Nocardioidaceae showed that strain NAA- $13^{\mathrm{T}}$ fell within the evolutionary radiation occupied by the genus Nocardioides (Fig. 1). Strain NAA- $13^{\mathrm{T}}$ formed a distinct lineage within the genus Nocardioides, a phyletic line that was supported by all of the tree-making algorithms. The $16 \mathrm{~S}$ rRNA sequence similarity between strain NAA- $13^{\mathrm{T}}$ and the type strains of the genus Nocardioides ranged from 93.6 to $96.6 \%$. It is also apparent from Fig. 1 that the isolate was loosely associated with the type strains of Nocardioides insulae DS- $51^{\mathrm{T}}$ (94.9\% similarity), Nocardioides pyridinolyticus KCTC $0074 \mathrm{BP}^{\mathrm{T}}$ (96.5\% similarity) and Nocardioides aquiterrae $\mathrm{GW}-9^{\mathrm{T}}(96.6 \%$ similarity), although these relationships were not supported by a high bootstrap value $(75 \%)$. It is clear that the observed divergence values with respect to all recognized Nocardioides species $(>3 \%)$ are consistent with separate species status (Stackebrandt \& Goebel, 1994). Further evidence for the separate species status of strain NAA- $13^{\mathrm{T}}$ comes from phenotypic data.

Chemosystematic studies were carried out to establish whether strain NAA $-13^{\mathrm{T}}$ had a chemical profile that was consistent with its assignment to the genus Nocardioides. Biomass of NAA $-13^{\mathrm{T}}$ was obtained after growing the strain on R2A at $25^{\circ} \mathrm{C}$ for 3 days. Fatty acid methyl esters were prepared, separated and identified according to the instructions of the Microbial Identification system
(Microbial ID; MIDI) (Sasser, 1990). Purified cell-wall preparations were obtained by the method of Schleifer \& Kandler (1972) and the isomer type of the diamino acid in the cell-wall peptidoglycan was analysed using TLC according to the method described by Schleifer (1985). Menaquinones were extracted and analysed by HPLC as described by Collins (1994) along with $N$. pyridinolyticus KCTC $0074 \mathrm{BP}^{\mathrm{T}}$ as a reference strain. The DNA $\mathrm{G}+\mathrm{C}$ content of strain NAA- $13^{\mathrm{T}}$ was estimated in duplicate as described by Mesbah et al. (1989). Strain NAA-13 ${ }^{\mathrm{T}}$ contained LL-diaminopimelic acid (LL-DAP) as the diagnostic diamino acid in the cell wall. The predominant isoprenoid quinone was a tetrahydrogenated menaquinone with eight isoprene units $\left[\mathrm{MK}-8\left(\mathrm{H}_{4}\right)\right]$ and the isolate possessed straight-chain, branched, unsaturated and 10methyl fatty acids (Supplementary Table S1, available in IJSEM Online). The major fatty acids were iso- $\mathrm{C}_{16: 0}$ $(19.93 \%)$ and $\mathrm{C}_{17: 0}(19.90 \%)$. All of these properties, including fatty acid composition, are typical of Nocardioides species (Yoon et al., 1997, 2004, 2007a, b; Lee, 2007). The DNA G + C content of strain NAA- $13^{\mathrm{T}}$ was $71.8 \pm 1.0 \mathrm{~mol} \%$, which is in the range reported for Nocardioides species $(67.0-74.8 \mathrm{~mol} \%)$ (Yoon et al., 2007a, b; Lee, 2007; Choi et al., 2007).

Standard physiological and biochemical tests were performed as described previously (Smibert \& Krieg, 1994). Additional biochemical tests were performed using the API ZYM, API 20NE and API Coryne (all bioMérieux) microtest systems according to the methods outlined by the manufacturer. Utilization of various substrates was also determined by inoculating API $50 \mathrm{CH}$ strips with cells suspended in AUX medium (bioMérieux). Hydrolysis of casein, starch, corn oil, and Tweens 20, 40, 60 and 80 was tested using R2A as the basal medium. DNase test agar (BD Difco) was used to assay DNase activity. Sensitivity to antibiotics was examined after spreading cells (0.5 McFarland standard) on R2A agar. The discs contained the following antibiotics: ampicillin $(10 \mu \mathrm{g})$, ceftizoxime $(30 \mu \mathrm{g})$, chloramphenicol $(30 \mu \mathrm{g})$, gentamicin $(10 \mu \mathrm{g})$, kanamycin $(30 \mu \mathrm{g})$, nalidixic acid $(30 \mu \mathrm{g})$, novobiocin $(30 \mu \mathrm{g})$, rifampicin $(5 \mu \mathrm{g})$, penicillin $\mathrm{G}(10 \mu \mathrm{g})$, streptomycin $(10 \mu \mathrm{g})$, tetracycline $(30 \mu \mathrm{g})$ or sulfamethoxazole $(23.75 \mu \mathrm{g})$ plus trimethoprim $(1.25 \mu \mathrm{g})$. The effects of the antibiotics on cell growth were assessed after 3 days incubation and susceptibility was scored on the basis of the distance from the edge of the clear zone to the disc. Detailed phenotypic and biochemical analyses of strain NAA- $13^{\mathrm{T}}$ are provided in Table 1 and in the species description. Phenotypic characteristics that differentiate strain NAA- $13^{\mathrm{T}}$ from its closest neighbours are presented in Table 1.

From the above data, it is evident that isolate NAA- $13^{\mathrm{T}}$ exhibits an overall chemotaxonomic profile that is consistent with those of members of the genus Nocardioides. Phylogenetic analysis based on 16S rRNA gene sequencing further confirmed its provisional assignment and clearly demonstrated that isolate NAA-13 ${ }^{\mathrm{T}}$ 


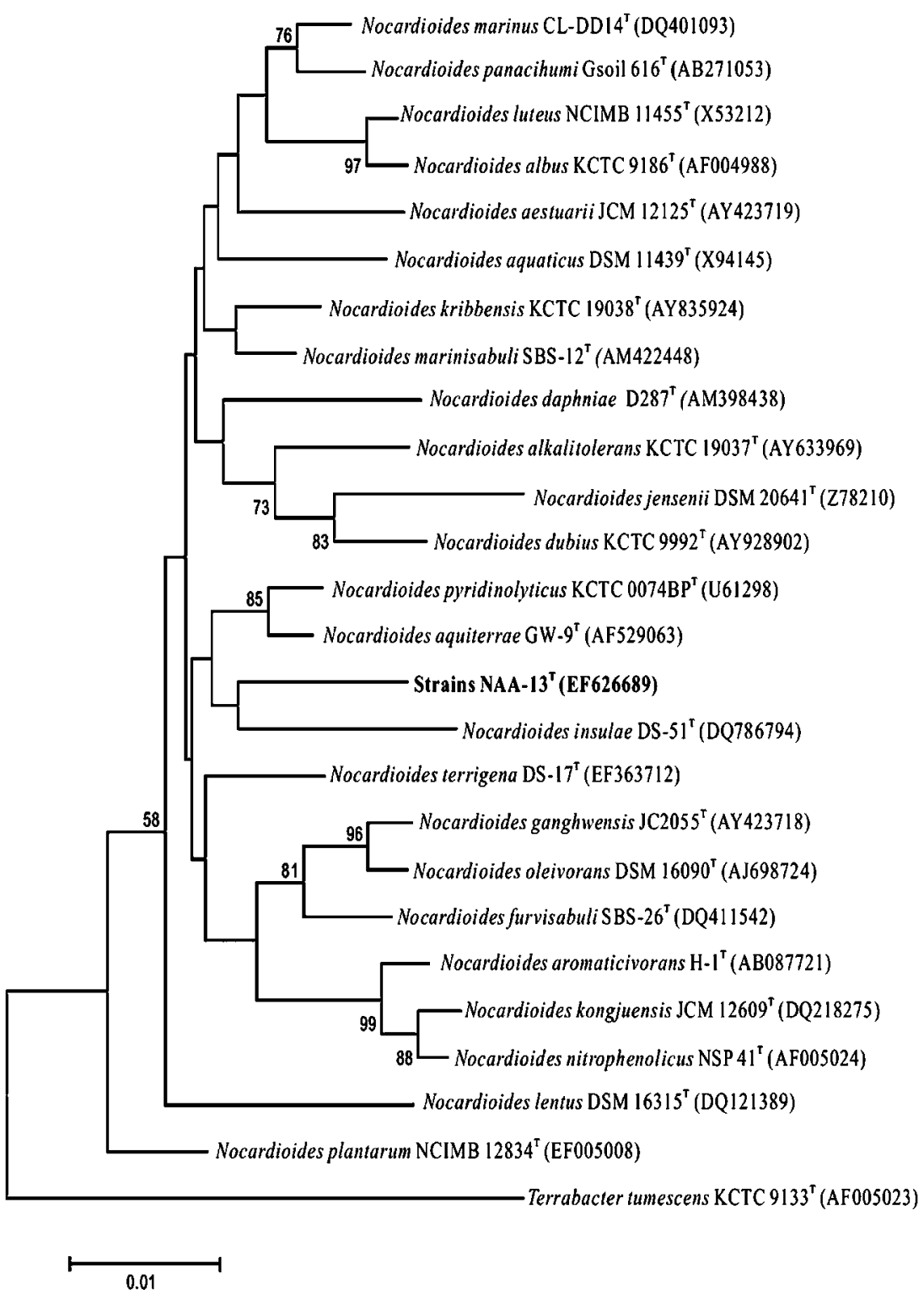

Fig. 1. Phylogenetic analysis based on $16 \mathrm{~S}$ rRNA gene sequences available from the Ribosomal Database Project and NCBI/ GenBank (accession numbers are given in parentheses) constructed after multiple alignments of data showing the position of strain NAA $-13^{\top}$ in the genus Nocardioides. Distances and clustering with the neighbourjoining method were determined by using the software package BioEdit. Numbers at the nodes are bootstrap values (\%) based on 1000 resampled datasets; only values above $50 \%$ are given. Bar, 0.01 substitutions per nucleotide position. represents an unknown subline within the genus Nocardioides. Biochemically, isolate NAA- $13^{\mathrm{T}}$ can be differentiated from the phylogenetically and biochemically most closely related species of the genus Nocardioides (Table 1). On the basis of phenotypic, chemotaxonomic and phylogenetic evidence, it is apparent that strain NAA$13^{\mathrm{T}}$ represents a novel species within the genus Nocardioides, for which the name Nocardioides fonticola sp. nov. is proposed.

\section{Description of Nocardioides fonticola sp. nov.}

Nocardioides fonticola [fon.ti.co'la. L. masc. n. fons, fontis a spring, fountain; L. suff. -cola (from L. masc. or fem. n. incola) an inhabitant of a place, a resident; N.L. n. fonticola an inhabitant of a fountain or spring].
Gram-positive and strictly aerobic. Oxidase-negative, catalase-positive and non-acid-fast. No endospore formation. Cells are non-motile rods, approximately $0.8 \mu \mathrm{m}$ wide and 2.0-9.0 $\mu \mathrm{m}$ long. Substrate or aerial mycelium is not observed. Colonies on R2A are pale yellowish in colour, circular and convex with entire edges. Colonies are approximately $0.9-1.0 \mathrm{~mm}$ in diameter after 3 days (on $\mathrm{R} 2 \mathrm{~A}$ at $25{ }^{\circ} \mathrm{C}$ ) of incubation and reach a maximum of $2 \mathrm{~mm}$ after 5 days of growth. Growth occurs at 0.5-1.0\% (w/v) $\mathrm{NaCl}, \mathrm{pH} 5-9$ and $25-37{ }^{\circ} \mathrm{C}$, with optimum growth at $0.5 \%(\mathrm{w} / \mathrm{v}) \mathrm{NaCl}, \mathrm{pH} 7-8$ and $30{ }^{\circ} \mathrm{C}$. Starch, skimmed milk, and Tweens 20, 40, 60 and 80 are hydrolysed. DNasepositive and lipase (corn oil)-negative. The following characters are positive (API 20NE test) for the type strain: aesculin hydrolysis, gelatin hydrolysis, $\beta$-galactosidase and assimilation of glucose and mannitol. Negative for nitrate 
Table 1. Differential phenotypic characteristics between Nocardioides fonticola sp. nov. strain $N A A-13^{\top}$ and closely related Nocardioides species

Strains: 1, N. fonticola sp. nov. NAA-13 ${ }^{\mathrm{T}} ; 2$, N. insulae DS-51 ${ }^{\mathrm{T}}$ (Yoon et al., 2007a); 3, N. pyridinolyticus KCTC 0074BP ${ }^{\mathrm{T}}$ (Yoon et al., 1997); 4, N. aquiterrae GW $-9^{\mathrm{T}}$ (Yoon et al., 2004); 5, N. terrigena DS- $17^{\mathrm{T}}$ (Yoon et al., 2007b). +, Positive; -, negative; w, weakly positive. All strains listed are Gram-positive and positive for catalase, hydrolysis of casein and gelatin, utilization of glucose, cellobiose and D-xylose, and esterase lipase (C8). All strains are negative for hydrolysis of urea, lipase (C14), $\alpha$-chymotrypsin, $\alpha$-galactosidase, $\beta$-glucuronidase, $N$-acetyl- $\beta$-glucosaminidase, $\alpha$-mannosidase and $\alpha$-fucosidase.

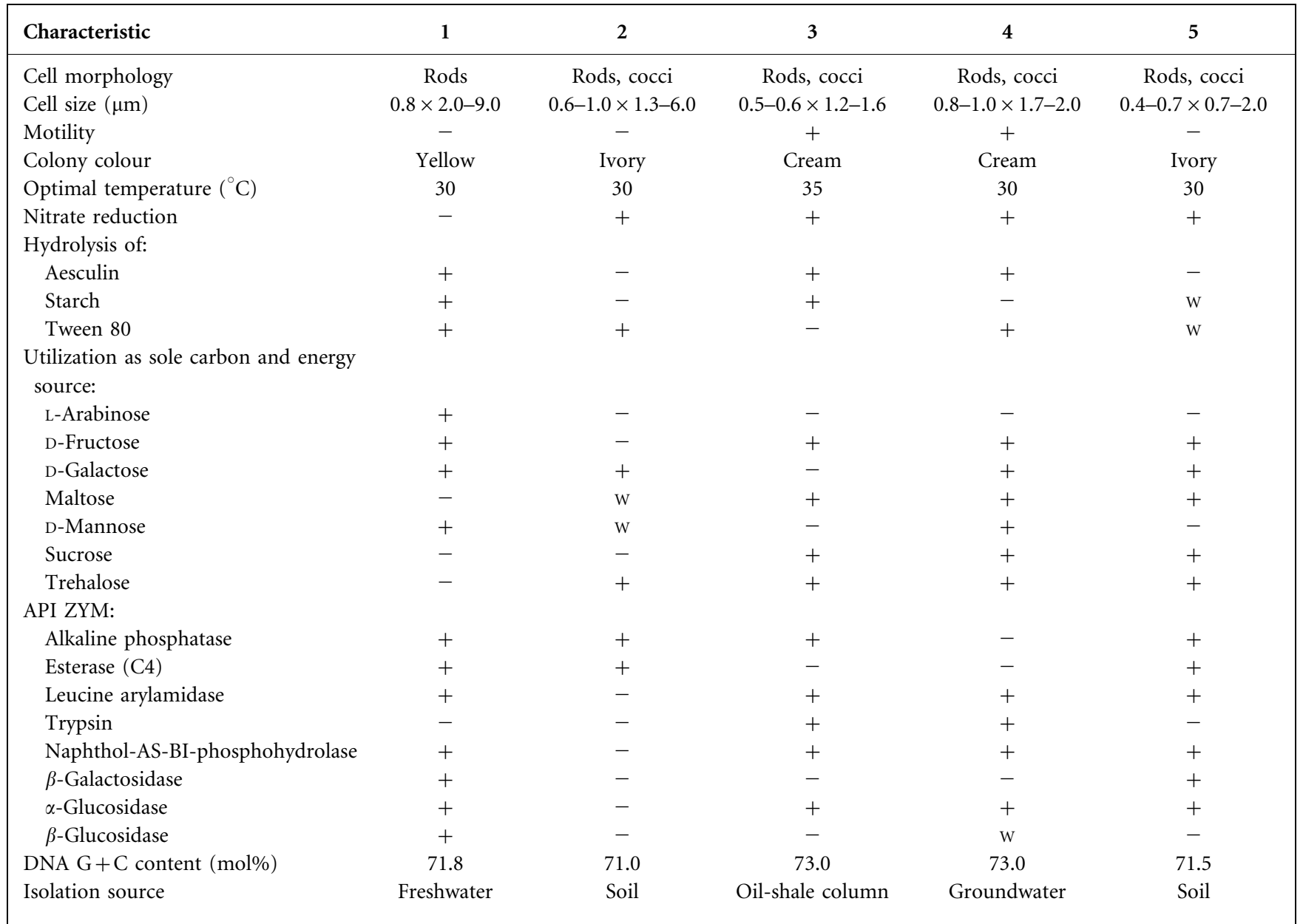

reduction, indole production, glucose fermentation, arginine dihydrolase, urease, and assimilation of $\mathrm{N}$-acetylglucosamine, gluconate, malate, caprate, adipate, citrate and phenylacetate. Strain NAA- $13^{\mathrm{T}}$ is positive (API ZYM test) for alkaline phosphatase, C4 esterase, C8 lipase, leucine arylamidase, acid phosphatase, naphthol-AS-BI-phosphohydrolase, $\beta$-galactosidase, $\alpha$-glucosidase and $\beta$-glucosidase, but is negative for C14 lipase, valine arylamidase, cystine arylamidase, trypsin, $\alpha$-chymotrypsin, $\alpha$-galactosidase, $\beta$-glucuronidase, $N$-acetyl- $\beta$-glucosaminidase, $\alpha$ mannosidase and $\alpha$-fucosidase. Positive (API Coryne test) for pyrazinamidase, pyrrolidonyl arylamidase, alkaline phosphatase, $\beta$-galactosidase, $\alpha$-glucosidase, and aesculin and gelatin hydrolysis, but negative for nitrate reduction, $\beta$-glucuronidase, $N$-acetyl- $\beta$-glucosaminidase, urease, and acid production from D-glucose, D-xylose, D-mannitol, maltose, D-lactose, sucrose, D-ribose and glycogen.
Resistant to nalidixic acid, ceftizoxime and sulfamethoxazole/trimethoprim antibiotics and sensitive to ampicillin, chloramphenicol, gentamicin, kanamycin, novobiocin, rifampicin, penicillin $\mathrm{G}$, streptomycin and tetracycline. Major menaquinone is $\mathrm{MK}-8\left(\mathrm{H}_{4}\right)$. Cell wall diamino acid is LL-DAP. Major fatty acids are iso- $\mathrm{C}_{16: 0}(19.9 \%), \mathrm{C}_{17: 0}$ $(19.9 \%), \mathrm{C}_{17: 1} \omega 8 c(13.3 \%)$ and $\mathrm{C}_{18: 1} \omega 9 c(11.7 \%)$. The DNA G $+\mathrm{C}$ content of the type strain is $71.8 \mathrm{~mol} \%$.

The type strain, NAA-13 ${ }^{\mathrm{T}} \quad\left(=\mathrm{LMG} \quad 24213^{\mathrm{T}}=\mathrm{BCRC}\right.$ $16874^{\mathrm{T}}$ ), was isolated from spring water, southern Taiwan.

\section{Acknowledgements}

W.-M. C. was supported by grants from the National Science Council, Taipei, Taiwan, Republic of China (NSC 95-2320-B-022-001-MY2 and 96-2313-B-022-001-MY3). 


\section{References}

Chen, W. M., Laevens, S., Lee, T. M., Coenye, T., de Vos, P., Mergeay, M. \& Vandamme, P. (2001). Ralstonia taiwanensis sp. nov., isolated from root nodules of Mimosa species and sputum of a cystic fibrosis patient. Int J Syst Evol Microbiol 51, 1729-1735.

Choi, D. H., Kim, H. M., Noh, J.-H. \& Cho, B. C. (2007). Nocardioides marinus sp. nov. Int J Syst Evol Microbiol 57, 775-779.

Chung, Y. C., Kobayashi, T., Kanai, H., Akiba, T. \& Kudo, T. (1995). Purification and properties of extracellular amylase from the hyperthermophilic archeon Thermococccus profundus DT5432. Appl Environ Microbiol 61, 1502-1506.

Collins, M. D. (1994). Isoprenoid quinones. In Chemical Methods in Prokaryotic Systematics, pp. 265-309. Edited by M. Goodfellow \& A. G. O’Donnell. Chichester: Wiley.

Felsenstein, J. (1981). Evolutionary trees from DNA sequences: a maximum likelihood approach. J Mol Evol 17, 368-376.

GCG (1995). Wisconsin Package Version 8.1 Program Manual. Madison, WI: Genetics Computer Group.

Hall, T. A. (1999). BioEdit: a user-friendly biological sequence alignment editor and analysis program for Windows 95/98/NT. Nucleic Acids Symp Ser 41, 95-98.

Hendrickson, D. A. \& Krenz, M. M. (1991). Reagents and stains. In Manual of Clinical Microbiology, pp. 1289-1314. Edited by A. Balows, W. J. Hausler, Jr, K. L. Herrmann, H. D. Isenberg \& H. J. Shadomy. Washington, DC: American Society for Microbiology.

Jukes, T. H. \& Cantor, C. R. (1969). Evolution of protein molecules. In Mammalian Protein Metabolism, vol. 3, pp. 21-132. Edited by H. N. Munro. New York: Academic Press.

Kluge, A. G. \& Farris, F. S. (1969). Quantitative phyletics and the evolution of anurans. Syst Zool 18, 1-32.

Kumar, S., Tamura, K. \& Nei, M. (2004). MEGA3: integrated software for Molecular Evolutionary Genetics Analysis and sequence alignment. Brief Bioinform 5, 150-163.

Lee, S. D. (2007). Nocardioides furvisabuli sp. nov., isolated from black sand. Int J Syst Evol Microbiol 57, 35-39.

Mesbah, M., Premachandran, U. \& Whitman, W. B. (1989). Precise measurement of the $\mathrm{G}+\mathrm{C}$ content of deoxyribonucleic acid by highperformance liquid chromatography. Int J Syst Bacteriol 39, 159-167.
Powers, E. M. (1995). Efficacy of the Ryu nonstaining KOH technique for rapidly determining Gram reactions of food-borne and waterborne bacteria and yeasts. Appl Environ Microbiol 61, 3756-3758.

Prauser, H. (1976). Nocardioides, a new genus of the order Actinomycetales. Int J Syst Bacteriol 26, 58-65.

Prauser, H. (1989). Genus Nocardioides Prauser 1976. In Bergey's Manual of Systematic Bacteriology, vol. 4, pp. 2371-2375. Edited by S. T. Williams, M. E. Sharpe \& J. G. Holt. Baltimore: Williams \& Wilkins.

Saitou, N. \& Nei, M. (1987). The neighbor-joining method: a new method for reconstructing phylogenetic trees. Mol Biol Evol 4, 406-425.

Sasser, M. (1990). Identification of bacteria by gas chromatography of cellular fatty acids, MIDI Technical Note 101. Newark, DE: MIDI Inc.

Schleifer, K. H. (1985). Analysis of the chemical composition and primary structure of murein. Methods Microbiol 18, 123-156.

Schleifer, K. H. \& Kandler, O. (1972). Peptidoglycan types of bacterial cell walls and their taxonomic implications. Bacteriol Rev 36, 407-477.

Smibert, R. M. \& Krieg, N. R. (1994). Phenotypic characterization. In Methods for General and Molecular Bacteriology, pp. 607-654. Edited by P. Gerhardt, R. G. E. Murray, W. A. Wood \& N. R. Krieg. Washington, DC: American Society for Microbiology.

Stackebrandt, E. \& Goebel, B. M. (1994). Taxonomic note: a place for DNA-DNA reassociation and $16 \mathrm{~S}$ rRNA sequence analysis in the present species definition in bacteriology. Int J Syst Bacteriol 44, 846-849.

Stackebrandt, E., Rainey, F. A. \& Ward-Rainey, N. L. (1997). Proposal for a new hierarchic classification system, Actinobacteria classis nov. Int J Syst Bacteriol 47, 479-491.

Yoon, J.-H., Rhee, S.-K., Lee, J.-S., Park, Y.-H. \& Lee, S. T. (1997). Nocardioides pyridinolyticus sp. nov., a pyridine-degrading bacterium isolated from the oxic zone of an oil shale column. Int J Syst Bacteriol 47, 933-938.

Yoon, J.-H., Kim, I.-G., Kang, K. H., Oh, T.-K. \& Park, Y.-H. (2004). Nocardioides aquiterrae sp. nov., isolated from groundwater in Korea. Int J Syst Evol Microbiol 54, 71-75.

Yoon, J.-H., Kang, S.-J., Lee, C.-H. \& Oh, T.-K. (2007a). Nocardioides insulae sp. nov., isolated from soil. Int J Syst Evol Microbiol 57, 136-140.

Yoon, J.-H., Kang, S.-J., Lee, S.-Y. \& Oh, T.-K. (2007b). Nocardioides terrigena sp. nov., isolated from soil. Int J Syst Evol Microbiol 57, 2472-2475. 